\title{
ANALISIS FUNGSI PERIBAHASA JEPANG YANG MENGANDUNG UNSUR BINATANG
}

\section{Suhervina Sinta Wati ${ }^{1}$, Hendri Zalman ${ }^{2}$.}

Program Studi Pendidikan Bahasa Jepang, Bahasa dan Sastra Inggris, Fakultas Bahasa dan Seni, Universitas Negeri Padang, Solok, $27388^{1}$

Program Studi Pendidikan Bahasa Jepang, Bahasa dan Sastra Inggris, Fakultas Bahasa dan Seni, Universitas Negeri Padang, Jl. Prof. Dr. Hamka Air Tawar, Padang, 25131 ${ }^{2}$ Email Penulis: Suhervina.tuan93@gmail.com

\begin{tabular}{lc}
\hline \multicolumn{3}{l}{ Sejarah Artikel } \\
\hline Submit $\quad: 2020-11-04$ \\
Diterima $: 2020-11-05$ \\
Diterbitkan : 2021-06-09
\end{tabular}

\section{Kata Kunci:}

Analis, fungsi,peribahasa ,binatang.

\begin{abstract}
Abstrak
Japanese proverb is an expression which is figurately by someone to another in situation, advice, life experience, and a game. In Japanese proverb, there are a lot of using the parable or comparison, one of their subject used in, it is animals. Japenese proverb is one of the language form that is hard to be learned and understood, especially for the foreign learner of Japanese language (example Indonesian speaker). This research discusses about the analysis of Japenese proverb which contains the animals word existing in happy lilac website. The purpose of this research is to know about kotowaza functions that contain of animals word in that website. The data in this research is kotozawa that contain of animal words in the website. The method in this research is qualitative descriptive. The technique of data collection in this research is the library technique. Based on the research result, it can be found that 23 from 210 kotozawa formed from animal words, 7 kotozawa have offensive function (Kougekiteki Kotowaza), 6 kotowaza have empiric function (Keikenteki Kotowaza), 10 kotowaza have didactive function (Kyoukunteki Kotowaza) and none of kotowaza that functioned as game (Kyoukunteki Kotowaza).
\end{abstract}




\section{PENDAHULUAN}

Setiap negara memiliki bahasanya sendiri. Bahasa yang dipakai dalam suatu negara disebut dengan bahasa nasional, yaitu bahasa yang dijadikan standar di suatu negara yang memiliki banyak bahasa karena perkembangan sejarah, kesepakatan bangsa, atau ketetapan perundang-undangan (Kridalaksana, 2011). Selain menguasai bahasa nasional, pada era globalisasi ini manusia juga dituntut untuk menguasai bahasa asing guna dapat berkomunikasi dengan orang di seluruh dunia. Di Indonesia, banyak bahasa asing yang dipelajari salah satunya bahasa Jepang. Mempelajari bahasa Jepang tidak hanya belajar mengenai cara berbicara dengan bahasa tersebut, juga belajar memaknai bahasa itu sendiri, baik makna sebenarnya maupun makna kiasan, seperti di dalam ungkapan.

Ungkapan yang di dalamnya mengandung makna kiasan yang dapat dmengerti oleh orang yang mendengarkan atau oran yang membaca karena samasama hidup dalam ruang lingkup budaya yang sama. Salah satu penggunaan ungkapan yang digunakan untuk menyampaikan bahasa kiasan adalah peribahasa (Tim ilmu bahasa, 2016).

Makna dalam sebuah peribahasa dapat berisi perbandingan, nasihat, tingkah laku, maupun prinsip hidup. Menurut Kridalaksana (2008), peribahasa adalah penggalan kalimat, bentuk, makna dan fungsinya bersifat secara turun temurun yang digunakan dalam percakapan, memberi nasihat, pengajaran atau pedoman hidup. Dalam bahasa Jepang peribahasa disebut dengan kotowaza.

Kotowaza adalah salah satu bentuk bahasa yang susah untuk dipelajari dan dipahami, terutama bagi pembelajaran bahasa Jepang penutur asing (misalnya penutur Indonesia). Penyebabnya adalah karena kotowaza banyak menggunakan perumpamaan/perbandingan. Salah satu bentuk objek perumpamaan/perbandingan yang banyak digunakan dalam kotowaza adalah binatang.

Adapun fungsi Kotowaza diklasifikasikan kedalam 4 fungsi yaitu, kougekiteki kotowaza (peribahasa yang bersifat ofensif), keikenteki kotowaza (peribahasa yang bersifat empirik), kyoukunteki kotowaza (peribahasa yang bersifat didaktif), yuugitekina kotowaza (peribahasa yang bersifat permainan). Salah satu contoh kotowaza yang mengandung unsur binatang

蛙の子は蛙。

Kaeru no ko wa kaeru.

Artinya: Anak katak adalah anak katak

Sumber: https://happylilac.net/sy-kotowaza_list.html

Kotowaza di atas memiliki makna “ anak katak adalah anak katak". Maksudnya adalah seorang anak tidak akan jauh berbeda dari orang tuanya baik fisik maupun sifat dan tingkah lakunya. Apabila orang tua mempunyai sifat suka menolong orang lain, maka sang anak biasanya juga akan memiliki sifat yang tidak jauh berbeda. Begitupun sebaliknya, jika orang tua memiliki sifat yang senang menghardik atau bersifat keras, maka sang anakpun berkemungkinan besar mewarisi sifat tersebut. 
Dari makna kotowaza di atas dapat disimpulkan bahwa kotowaza tersebut bersifat ofensif, karena kotowaza tersebut biasa digunakan untuk mengkritik dan menyindir lawan bicara.

Dalam mengklasifikasikan kotowaza berdasarkan fungsinya perlu untuk mengetahui maknanya. Kotowaza memiliki makna yang sulit untuk dipahami, karena adanya perbedaan budaya yang mempengaruhi kotowaza.

「所変われば品変わる」という彥があります。土地が違えば、それぞ れの土地に他の所と異なった産物があり、風俗や習慣なども違うとい う意味です」。

'Tokoro kawareba shina kawaru' to iu kotowaza ga arimasu. Tochi ga chigaeba, sorezore no tochi ni hoka no tokoro to konatta sanbuttsu ga ari, fuuzoku ya shuukan nado mo chigau to iu imi desu.

"Ada peribahasa yang berbunyi (jika tempatnya berubah maka bendanya juga berubah). Artinya adalah jika berbeda lokasi daerahnya, maka tradisi, kebiasaan dan yang lainnya juga berbeda karena di masing-masing daerah ada barang yang berbeda dengan di tempat lain, tradisi, kebiasaan dan yang lainnya juga berbeda (Kawase dalam Yohani, 2016).

Berdasarkan hal di atas karena Jepang memiliki bahasa dan budaya yang berbeda dengan Indonesia, pembelajar asing akan sulit untuk memahami makna kotowaza dan akan sulit pula mengklasifikasikan fungsinya. Sehingga ketika pembelajar bahasa Jepang berkomunikasi dengan penutur asli yang menggunakan kotowaza, dapat mengakibatkan terjadinya kesalahan dalam memahami makna yang tersirat dalam kotowaza tersebut, karena dalam kotowaza hampir tidak ada yang memiliki arti yang sama dengan peribahasa Indonesia. Hal ini dikarenakan terbentuknya kotowaza tergantung kepada karakteristik dan cara berfikir orang Jepang (Iskandar, 2006).

\footnotetext{
${ }^{1}$ Mahasiswa Prodi Pendidikan Bahasa Jepang FBS UNP lulus pada tanggal 20 desember 2020

${ }^{2}$ Dosen Prodi Pendidikan Bahasa Jepang FBS UNP
} 


\section{METODE PENELITIAN}

Penelitian kualitatif adalah jenis penelitian yang digunakan dalam riset ini, sementara metode yang digunakan dalam riset ini adalah metode analisis deskriptif. Penelitian kualitatif merupakan riset yang bertujuan untuk memahami fenomena yang dialami oleh subjek riset, contohnya : perilaku, persepsi, motivasi, tindakan dengan cara deskripsi dalam bentuk kata-kata dan bahasa, pada suatu konteks khusus yang alamiah dan dengan memanfaatkan berbagai metode alamiah (Moleong, 2005). Dalam penelitian ini peneliti menggunakan data kotowaza yang berbentuk dokumen dan elektronik lalu mendeskripsikan data tersebut dalam bentuk kata-kata, oleh karena itulah riset ini disebut penelitian kualitatif.

Sumber data dalam penelitian ini adalah kotowaza yang terdapat pada situs happy lilac. Bahan data yang digunakan dalam penelitin ini adalah seluruh kotowaza yang mengandung unsur binatang yang terdapat dalam situs happy lilac.

Adapun untuk mengumpulkan data digunakan teknik pustaka. Teknik pustaka merupakan metode pengumpulan data yang berupa dokumen tertulis, baik elektronik maupun berbentuk foto. Menurut Arikunto (dalam Haq dkk, 2018) peneliti menggunakan sumber tertulis untuk memperoleh data. Sumber tertulis tersebut adalah situs happy lilac, yaitu kotowaza yang terbentuk dari unsur binatang yang berbuntuk dokumen elektronik. Kemudian mengklasifikasikan data menggunakan kode data dalam kartu data, data yang telah diklasifikasikan ke dalam kartu data dicari makna dan fungsinya.

\section{HASIL DAN PEMBAHASAN \\ Temuan Penelitian}

Berdasarkan data analisis kotowaza yang menggunakan unsur binatang dalam situs web happy lilac, peneliti menemukan beberapa kotowaza yang menggunakan unsur binatang. Untuk lebih jelasnya data penelitian ini akan ditampilkan dalam bentuk tabel.

Table 1. Unsur Binatang dan Fungsi Kotowaza

\begin{tabular}{lll}
\hline No. & Kategori & Jumlah \\
\hline 1 & Unsur binatang & 16 \\
2 & Fungsi & \\
& a. Fungsi ofensif & 7 \\
b. Fungsi empirik & 6 \\
c. Fungsi didaktif & 10 \\
& d. Fungsi permainan & 0 \\
\hline & $\mathbf{2 3}$ \\
\hline
\end{tabular}

Berdasarkan table di atas dapat diketahui bahwa di dalam situs web happy lilac terdapat 23 kotowaza yang mengandung unsur binatang. Peneliti menemukan 7 kotowaza yang memiliki fungsi kougekiteki kotowaza (ofensif), yang terdiri dari 6 kotowaza yang memiliki fungsi keikenteki kotowaza (empirik), 10 kotowaza yang 
memiliki fungsi kyoukunteki kotowaza (didaktif) dan tidak ditemukannya kotowaza yang bersifat kyoukunteki kotowaza (permainan).

\section{Kougekiteki Kotowaza (Ofensif)}

Peribahasa berjenis ini umumnya berguna sebagai alat untuk mengadu kepandaian seseorang dalam berbicara, juga digunakan untuk mengkritik dan menyinggung orang yang diajak bicara atau musuh dalam suatu pertandingan. Berikut adalah beberapa contoh dari 7 data kougekiteki kotowaza.

a) Data [04]

$$
\text { うまみみ㱛んぶつ }
$$

馬の耳に念仏

\section{Uma no mimi ni nenbutsu}

Artinya: nenbutsu (do'a agama budha) di telinga kuda.

\section{[HL: No 31]}

Kotowaza di atas menggunakan kata bianatang, yaitu uma (kuda). Yang dimaksud dengan “nenbutsu di telinga kuda” adalah 「人の意見や忠告を聞き流してしまい 、何とも思わないことのたとえ」 hito no iken ya chuukoku wo kikinagashite shimai, nantomo omowanai koto no tatoe, tidak peduli seberapa banyak kita menasehati dia tidak akan mendengarkannya. Dalam kotowaza ini mengunakan kata "uma" dan "nenbutsu", kuda merupakan hewan yang tidak memiliki akal dan pikiran jadi meskipun kita mebisikkan sesuatu di telinganya, dia tidak akan mendengarkannya meskipun yang kita baca adalah nenbutsu.

Kotowaza ini bertujuan untuk menyindir seseorang yang tidak mau mendengarkan pendapat maupun nasehat orang lain, hanya mementingkan pendapat sendiri. Artinya kotowaza ini digunakan untuk menyinggung orang yang keras kepala.

b) Data [05]

\section{蛙の子は蛙}

Kaeru no ko wa kaeru

Artinya: anak katak adalah katak. [HL: No 47]

Kotowaza diatas makna “ anak katak adalah anak katak”. Maksudnya adalah

「平凡な親からは平凡な子どもしか生まれないということ。子どもの才能な どは、結局は親に似るものだということ」 heibon na oya kara wa heibon na kodomo shika umarenaito iu koto. Kodomo no saninou nado wa, kekkyoku wa oya ni niru mono da to iu koto, seorang anak tidak akan mirip dengan orang tuanya baik fisik maupun sifat dan tingkah lakunya. Apabila orang tua mempunyai sifat suka menolong orang lain, maka sang anak biasanya juga akan memiliki sifat yang tidak jauh berbeda. Begitupun sebaliknya, jika orang tua memiliki sifat yang senang menghardik atau bersifat keras, maka sang anakpun berkemungkinan besar mewarisi sifat tersebut.

Dari makna kotowaza di atas dapat disimpulkan bahwa kotowaza tersebut bersifat ofensif, karena kotowaza tersebut biasa digunakan untuk mengkritik dan menyindir lawan bicara. 
c) Data [06]

\section{犬猿の仲}

Kenen no naka

Artinya: anjing dan kera. [HL: No 48]

Kotowaza ini menggunakan kata anjing dan kera, dalam kehidupan nyata anjing dan kera merupakan hewan yang saling bertentangan dan tidak pernah akur. Kotowaza ini memiliki arti「犬と猿のように、二者の仲がとても悪いことのたとえ」inu to saru no youni nisha no naka ga totemo warui koto no tatoe, Kotowaza ini bertujuan untuk menyindir, yaitu menjelaskan hubungan antara dua orang atau lebih yang tidak pernah akur dan selalu berselisih saat bertemu.

\section{Keikenteki Kotowaza (Empirik)}

Peribahasa jenis ini merupakan yang paling banyak menempati peribahasa Jepang. Isi peribahasa ini berkaitan dengan sikap pengetahuan, hidup, kepercayaan, yang bisa berbeda ditiap daerahnya. Juga berhubungan dengan perikanan, teknik produksi seperti pertanian, cuaca, dan pengetahuan tentang kehidupan. Berikut adalah beberapa contoh dari 6 data keikenteki kotowaza.

a) Data [07]

亀の甲より年の劫

Kame no kou yori toshi no kou

Artinya: orang tua yang kaya akan pengalaman dan keberhasilan. [HL: No 58]

Dalam kotowaza ini menggunakan kata binatang, yaitu kame (penyu) yang merupakan hewan yang dipercaya memiliki umur yang panjang. kata toshi no kou menggambarkan orang tua. Kotowaza ini memiliki arti .「年長者が身に付けた長 年の経験や豊富な知識は大事にする べきだということ」nenchousha ga mi ni tsuketa naganen no keiken ya houfu na chisiki wa daiji ni suru beki da to iu koto, orang tua yang kaya akan pengalaman dan keberhasilan, merupakan Keikenteki Kotowaza (kotowaza yang bersifat empirik), yaitu merupakan sebuah pengalaman.

Orang yang sudah tua tentu akan memiliki lebih banyak pengalaman dan ilmu tentang hidup ini dari pada anak yang baru berumur lima tahun karena dia sudah lama hidup di dunia dan telah mengecam pahit manisnya kehidupan, oleh sebab itu kita menghormati orang tua sangatlah perlu karena bagaimanapun juga dia memiliki pengalaman dan ilmu tentang hidup lebih banyak daripada kita .

b) Data [08]

鴨が葱を背負って来る

Kamo ga negi wo seottekuru

Artinya: bebek yang membawa daun bawang di punggunya.

[HL: No 59]

Dalam kotowaza di atas menggunakan kata kamo (bebek) dan negi (daun bawang). di Jepang untuk membuat nabe bebek, daun bawang merupakan bahan yang sangat penting. Kotowaza ini memiliki makna「鴨が苟を背負つてきたら、すぐに鴨鍋 ができるように、好都合が重なり、さらに都合がいいことのたとえ」kamo ga negi wo seotte kitara,suguni kamo nabe ga dekiru youni, kou tsugou ga kasanari, sara ni tsugou ga ii koto no tatoe, bebek yang membawa daun bawang dipunggungnya, langsung bisa membuat nabe bebek. Menggambarkan sesuatu yang membuat nyaman . 
Kamo ga negi wo seottekuru merupakan sebuah ungkapan yang digunakan saat kita menglami kesulitan dan datanglah seseorang yang bisa menolong kita dalam mengatasi kesulitan tersebut, sehingga kita tidak perlu lagi berfikir untuk mengatasi kesulitan tersebut. Jadi kotowaza ini merupakan Keikenteki Kotowaza ( kotowaza yang bersifat empirik) yaitu yang berhubungan dengan sikap hidup.

c) Data [14]

鶴は千年、亀は万年

Tsuru wa senen, kame wa mannen

Artinya: bangau seribu tahun dan penyu sepuluh ribu tahun

[HL: No 115]

Kotowaza di atas menggunakan unsur binatang, yaitu tsuru (bangau) dan kame (penyu). Kedua hewan tersebut dipercaya memiliki umur yang panjang dan merupakan simbol ucapan selamat. kotowaza ini memiliki makna 「寿命が長くて 、めでたいことのたとえ」 jumyo ga nagakute me detai koto no tatoe, Karena sejak zaman purba penyu dan bangau sudah dianggap sebagai hewan berumur panjang, jadi kotowaza merupakan sebuah ungkapan do'a agar panjang umur dan selamat dalam kehidupan.

Biasanya kotowaza ini diungkapkan saat ulang tahun yang ditujukan kepada orang yang sudah memiliki ukur lebih dari lima puluh tahun keatas agar berumur panjang dan sehat selalu. Kotowaza ini merupakan Keikenteki Kotowaza (kotowaza yang bersifat empirik).

\section{Kyoukunteki Kotowaza (Didaktif)}

Merupakan jenis peribahasa yang berisi ajaran moral, pendidikan, etika, nasihat, yang dapat dijadikan sebagai patokan bagi seseorang dalam suatu perbuatan atau bertindak. Berikut adalah beberapa contoh dari 10 data kyoukunteki kotowaza.

a) Data [01]

魚心あれば水心

Uogokoro areba mizugokoro

Artinya: jika ada hati ikan ada hati air. [HL: No 24]

Kotowaza di atas memiliki makna「相手が好意を示すのならば、自分もそれに 応じて、好意をもって対応しよう、ということ」 aite ga koui wo shimesu no naraba, jibun mo soreni oujite, koui wo motte taiou shiyou, to iu koto, jika orang lain menyukai kita maka kita juga akan menyukai orang tersebut, sikap kita tergantung dengan sikap orang lain kepada kita. Di dalam kotowaza ini disebutkan Hati ikan , dan hati air, air merupakan tempat ikan untuk hidup, jika tidak ada air maka ikan tidak akan bisa hidup, ini tentang makhluk hidup dan tempat hidupnya.

Kotowaza ini menjelaskan sebuah nasihat, yaitu bersikap baiklah kepada orang yang tidak melakukan keburukan kepada kita. Bahwa dalam hidup manusia cenderung memperlakukan orang lain tergantung kepada sikap orang tersebut, apabila orang lain berbuat baik kepadanya maka ia akan balas juga dengan kebaikan, sebaliknya jika orang tersebut berbuat buruk maka tidak menutup kemungkinan akan dibalas dengan yang lebih buruk. Dari penjelasan diatas dapat disimpulkan kotowaza ini bersifat didaktif. 
b) Data [03]

鵜の真似をする烏

U no mane suru karasu

Artinya: gagak meniru burung komoran. [HL: No 30]

Kotowaza ini memiliki arti「カラスが鵜を真似て魚を捕ろうとしても、うまく いかない。身の程をわきまえず、人の真似をして失敗すること」karasu ga u wo manete sakana wo torou to shitemo, umaku ikanai. Mi no hodo wo wakimaezu, hito no mane wo shite shippai suru koto, Jika kamu meniru seseorang tanpa memikirkan kemampuanmu sendiri maka kamu akan gagal.

Di dalam kotowaza ini di sebutkan gagak dan komoran yang merupakan dua jenis burung yang berbeda, yaitu gagak merupakan burung pemakan bangkai, berbeda dengan komoran merupakan burung pemakan ikan yang biasanya hidup sekitar pantai atau perairan dan biasa terbang diatas permukaan laut untuk mencari makan. Bagi masyarakat jepang burung gagak merupakan hewan yang cerdas namun juga dikaitkan dengan pertanda buruk berbeda dengan burung komoran yang digunakan oleh masyarakat jepang untuk menangkap ikan, ini menjelaskan tentang perbedaan kedua burung tersebut.

Kotowaza ini menggambarkan sebuah nasehat, yaitu jadilah diri sendiri dan menerima kelebihan serta kekurangan kita, karena setiap kmanusia memiliki kemampuan masing-masing yang berbeda-beda, jika kita meniru seseorang diluar batas kemampuan kita maka kita akan gagal. Merupakan kyoukunteki kotowaza (peribahasa yang bersifat didaktif)

c) Data [19]

猫に小判

Neko ni koban

Artinya: koin emas untuk kucing [HL: No 149]

Makna kotowaza di atas adalah「価值のわからない者に貴重な品を与えても、 何の役にも立 たないことのたとえ」Kachi no wakaranai mono ni kichou na shina wo ataetemo, nan no yakuni mo tatanai koto no tatoe, tidak peduli seberharga apapun suatu benda, akan menjadi tidak berarti jika kita memberikannya kepada orang yang tidak mengerti dengan nilai benda tersebut.

Di dalam kotowaza di atas disebutkan neko (kucing) dan koban (koin emas) . Koban adalah koin yang terbuat dari emas dan berbentuk oval kecil yang digunakan di jepang pada era sebelum restorasi meiji 1868. kotowaza ini memiliki arti memberikan koin emas kepada kucing, bagi kucing emas tidak akan ada artinya. kotowaza ini menjelaskan sebuah nasihat tidak ada artinya memberikan benda yang berharga kepada orang yang tidak mengerti dengan nilai benda tersebut. Adapun fungsi kotowaza ini adalah kyoukunteki kotowaza (peribahasa yang bersifat didaktif).

\section{Yuugiteki Kotowaza (Permainan)}

Merupakan peribahasa untuk permainan, Biasa digunakan untuk mengisi waktu senggang pada saat tahun baru dengan beradu kemampuan menggunakan peribahasa. Dalam penelitian ini peneliti tidak menemukan satupun kotowaza yang mengandung unsur binatang bersifat permainan. 


\section{KESIMPULAN}

Dari hasil analisis dan pendataan pada kotowaza yang terdapat pada situs web happy lilac dapat disimpulkan bahwa dari 201 kotowaza terdapat 23 kotowaza yang terbentuk dari unsur binatang. 7 kotowaza yang memiliki fungsi ofensif (kougekiteki kotowaza), yang terdiri dari 6 kotowaza yang memiliki fungsi empirik (keikenteki kotowaza), 10 kotowaza yang memiliki fungsi didaktif (kyoukunteki kotowaza) dan tidak ditemukannya kotowaza yang bersifat permainan (kyoukunteki kotowaza). Dari data diatas dapat disimpulkan bahwa kotowaza Jepang lebih banyak yang berbentuk nasihat, ajaran moral dan etika dibandingkan dengan yang lainnya. Ini menandakan bahwa orang jepang lebih mementingkan nasehat dan etika bagaimana bersikap dan bertingkah laku sesama manusia.

\section{REFERENSI}

Haq, Zia Ul., Zalman, Hendri., \& Putri, Meira Anggia. 2018. “Analisis Fungsi Joshi Dalam Buku Teks Shin Nihongo No Kiso I Dan Shin Nihongo No Kiso II". Omiyage: Jurnal Bahasa dan Pembelajaran Bahasa Jepang. Vol.1, No. 3.

Iskandar, Rahmawati. 2006. Analisis Peribahasa Jepang Dan Indinesia Yang Menggunakan Kata "Kera" (Saru). Skripsi. Universitas Pendidikan Indonesia.

Kridalaksana, Harimurtati. 2008.Kamus Linguistik Edisi Keempat. Jakarta: Gramedia Pustaka Utama.

Moleong, Lexy J. 2005. Metodotologi Penelitian Kualitatif. Bandung: PT.Remaja Rosdakarya.

Tim Ilmu Bahasa. 2016. Rangkuman Pembahasan Sastra Indonesia. Jakarta Selatan: PT. Serambi Semesta Distribusi.

Yohani, Adisthi Marhta. 2016. Kotowaza Dalam Kajian Linguistic Kognitif. Izumi. Universitas Widyatama.

むすびドリル小学生、小学生用ことわざ一覧プリント、17 mei 2020, $<$ Https://happylilac.net/sy-kotowaza_list.html> [diakses pada 10 Juli 2020] 